\title{
Article
}

2020/12

\section{The legal position of bicycle deliverers in Austria (AT)}

\author{
CONTRIBUTOR Thomas Dullinger*
}

\section{Summary}

In Austria, a collective bargaining agreement (CBA) for bicycle deliverers has been in force since 1 January 2020. According to the contracting parties (the Austrian Chamber of Commerce and the Austrian Trade Union Federation), it is the first of its kind worldwide. ${ }^{1}$ On this occasion, this article examines the legal basis for employment in this sector and whether this long-awaited step will really lead to an improvement for bicycle deliverers.

Introductory remarks

Austrian employment law is in principle applicable only to employees. Those are persons obliged to work for another in a state of personal dependency (personal subordination). Performing work in a state of personal dependency means that work is carried out in a position of subordination, in other words, under the command, authority and control of another and using the resources belonging to another. Employees cannot freely decide when, where or which work they are to perform, as this depends on the employer's orders. If work is performed in such a manner, the employee enjoys the full protection of labour law (including CBAs). ${ }^{2}$ The intention of the parties to enter into a specific contract and the name of the agreement are not relevant. ${ }^{3}$

* Univ.-Ass. Mag. Thomas Dullinger is associated with Institut für Arbeitsund Sozialrecht, Universität Wien.

1. https://www.vida.at/cms/S03/S03_4.8.a/1342616918551/ kollektivvertrag/strasse/weltweit-erster-kv-fuer-fahrradbotenabgeschlossen (16.1.2020).

2. Melzer-Azodanloo, Labour Law in Austria[2] (2017) 43 f; Rebhahn in Neumayr/Reissner, Zeller Kommentar zum Arbeitsrecht3 (2018) § 1151 ABGB Rz 80

3. Rebhahn in Neumayr/Reissner, ZellKomm[3] § 1151 ABGB Rz 64; OGH 13.3.2002, 9 ObA 288/01w.
Only a few provisions of Austrian labour law ${ }^{4}$ are applicable to some working persons who cannot be qualified as employees, because they are not performing their work in personal subordination. The prerequisite for this is that these persons are economically dependent despite their personal independence (employee-like persons). Economic dependency in this sense does not mean that the employee depends on a salary to earn a living but that the working person, who has no contract of employment, works for others in a reduced kind of personal independency. Employee-like workers do not perform their duties in a relationship of comprehensive subordination - mostly they can organise for themselves when and where to work. However, they have only one, or a few, principals, and they do not have at their disposal their own establishment, essential work equipment or their own employees. This includes for example home workers, franchisees and so-called commercial representatives. ${ }^{5}$ Recently, this category experienced increased attention, as certain parts of doctrine consider solving the problem of dealing with new forms of work by qualifying them as employee-like. ${ }^{6}$

Bicycle deliverers in practice are often treated as (employee-like) self-employed. ${ }^{7},{ }^{8}$ The food delivery platform Mjam (previously foodora) for example employs only $10 \%$ of their riders under an employment contract. The rest are qualified as self-employed. ${ }^{9}$ There is no case law regarding bicycle deliverers working for platforms. However, the jurisprudence for example has qualified a pizza deliverer as an employee ${ }^{10}$ and there are also judgments qualifying newspaper deliverers as employees. ${ }^{11}$ The prevailing legal doctrine sees the qualification of bicycle deliverers as self-employed critically or rejects it. The main reason is the typically existing personal dependency with regard to working hours, place of work and work-related behaviour - not only but especially by using the app of the contractual

4. For instance the right to equal treatment, the Employees' Liability Act, the Act on Labour and Social Courts and the obligation to inform the working person of the essential aspects of the contract in written form.

5. Melzer-Azodanloo, Labour Law in Austria[2] $44 \mathrm{f}$.

6. See Risak/Dullinger, The concept of 'worker' in EU law (2018) 14 with further references.

7. https://www.weka-akademie.at/wekablog/fahrradzustellerkollektivvertrag-gegen-scheinselbststandigkeit (16.1.2020).

8. https://www.derstandard.at/story/2000108735317/wko-undgewerkschaft-einigten-sich-auf-fahrradzusteller-kv (16.1.2020).

9. https://orf.at/stories/3137503/ (16.1.2020).

10. OGH 26.7.2012, 8 ObA 56/11k; VwGH 3.11.2015, 2013/08/0153; 10.9.2014, Ro 2014/08/0069.

11. VwGH 14.10.2015, 2013/08/0226. 
partner. ${ }^{12}$ However, the decisive factor is always the specific conditions of the individual case. Therefore, a definite assessment is not possible.

\section{The CBA for bicycle deliverers}

The Austrian Trade Union Federation estimates that there are a few thousand bicycle deliverers in Austria, mainly in the larger cities (especially Vienna). ${ }^{13}$ The focus of the concluding parties was on food delivery and parcel delivery. ${ }^{14}$ However, only those who can be qualified as employees fall within the scope of the CBA, as according to Austrian law it is not possible to extend the effects of a CBA to self-employed persons.

The reason why the conclusion of this collective agreement has received widespread attention in Austria is that Austria has a very high CBA-coverage of 95\% to 98\% of employees. ${ }^{15}$ Accordingly branches without CBAs are rare in Austria. The reason for this high coverage is the fact that most employers are obliged to be members of the Austrian Chamber of Commerce which concludes most of the CBAs on the employer side. Therefore, most of the employers are bound by CBAs.

There are two main reasons for the remaining employment contracts not to be covered by a CBA. On the one hand, most but not all employers are obliged to be members of the Chamber of Commerce. Those who are not members are in principle not bound by CBAs concluded by the Chamber of Commerce. This for example is true for private employers who employ somebody in their household and employers who do not need a trade licence (Gemerbeberechtigung) because they act without the intention of making a profit. Employers who are not obliged to be members of the Chamber of Commerce may voluntarily join another employers' association. However, many employers do not make use of this possibility. In principle, no CBA applies to those employers. On the other hand, the Chamber of Commerce has not concluded CBAs for all activities carried out by its members. This second option is the absolute exception in labour law practice, but is true for this case and makes it so special.

The most noticeable aspect of the CBA for bicycle deliverers is the section regarding minimum wages and reimbursement of expenses (Article XVII). ${ }^{16}$ The mini-

12. Dullinger, Essenszustellung: foodora, in Lutz/Risak, Arbeit in der GigEconomy (2017) 186 (191 ff); Pfalz, Grundfragen der Plattformarbeit, in Kietaibl/Mos/er/Pacic, Gedenkschrift Robert Rebhahn 425 (429); Warter, Überlegungen zur Anwendbarkeit kollektivrechtlicher Bestimmungen bei Crowdwork, in Auer-Mayer/Felten, Festband Mosler und Pfeil 173 (174); de Brito/Ivansits, Crowdwork und Sozialversicherungsschutz, DRdA-infas 2017, 309 (310 ff).

13. https://orf.at/stories/3137496/ (16.1.2020); https:// www.derstandard.at/story/2000108735317/wko-und-gewerkschafteinigten-sich-auf-fahrradzusteller-kv (16.1.2020).

14. https://www.vida.at/cms/S03/S03_4.8.a/1342616918551/ kollektivvertrag/strasse/weltweit-erster-kv-fuer-fahrradbotenabgeschlossen (16.1.2020).

15. Melzer-Azodanloo, Labour Law in Austria[2] 51.

16. ARD 6667/2/2019; https://www.weka-akademie.at/wekablog/ fahrradzusteller-kollektivvertrag-gegen-scheinselbststandigkeit (16.1.2020); https://orf.at/stories/3137496/ (16.1.2020); https:// www.derstandard.at/story/2000108735317/wko-und-gewerkschafteinigten-sich-auf-fahrradzusteller-kv (16.1.2020). mum wage is set at $€ 1,506$ gross per month ${ }^{17}$ for a 40 hour week. By Austrian standards, this is very low but nevertheless a big improvement, because there is no statutory minimum wage in Austria and without a CBA, it is possible to agree on unreasonably low wages to the limit of immorality. ${ }^{18}$ When a deliverer uses his or her own bike he or she is entitled to an extra $€ 0.14$ per kilometre as a reimbursement for the wear of the bike. When a private smartphone is used the employee is entitled to $€ 20$ - in the case of full-time employees. Furthermore, the employer has to provide helmets, rain gear and gloves (Article IV.4).

Apart from these provisions, the CBA contains some provisions beneficial to employees, some provisions detrimental to employees and many provisions just repeating legislation or specifying general principles. The CBA for example allows the averaging of weekly working time over a period of 52 weeks with the effect that employees can work up to 48 hours in some weeks without entitlement to the $50 \%$ surcharge for working overtime. ${ }^{19}$ Furthermore, there is no surcharge for an existing time credit at the time of termination of employment (Article VI.2.4). Without the permission of the CBA this would not be possible. ${ }^{20}$ On the other hand, the CBA provides for a $100 \%$ surcharge for working at night that legislation does not guarantee. Overall, however, the collective agreement is rather brief and focuses on a few aspects of particular interest for this sector.

The relevance of the CBA for those not treated as employees

Some, however, see the collective agreement primarily as a strike against the (bogus) self-employment that prevails in this industry. ${ }^{21}$ At first sight, this view seems surprising, because bogus self-employed persons already have had the opportunity to take action against their bogus self-employment and genuine self-employed persons do not fall within the scope of the CBA. In practice, however, the existence of a collectively agreed minimum wage is of the utmost importance in combatting bogus self-employment. Many provisions in labour law are linked directly or indirectly to the agreed wage (for example continued remuneration or paid leave). If there is no minimum wage, it is possible to circumvent many of these provisions by skilful contract design and by reducing the agreed wage under the level one is willing to pay in total. In this case, most bogus self-employed employees will not take action against their employers, because it would not pay off. The existence of a minimum wage therefore increases the incentive to take action against bogus self-employment. However, in practice the opposite result is also conceivable, meaning that companies are increasingly resorting to (bogus) selfemployed persons due to the increased costs. Another possible effect would be an additional densification of

\footnotetext{
17. As is customary in Austria, this salary is due 14 times a year (Article XII).

18. OGH 26.11.2018, 8 Ob A 63/18z.

19. Article 4 para. 6 Working Time Act (Arbeitszeitgesetz).

20. Article 19 e para. 2 Working Time Act.

21. https://orf.at/stories/3137503/ (16.1.2020).
} 
workflows due to payment by hours worked, regardless of the number of deliveries made. ${ }^{22}$

The minimum wage is also important in social security law. Although the distinction between employed and self-employed persons is relevant for the classification in the social security system regardless of the amount of remuneration, the existence of a minimum wage extends the possibilities to take action. This is because social security contributions are not calculated according to the wage actually paid, but according to the wage to which an employee is entitled.

None of these arguments affect genuinely self-employed persons. However, as a result of the CBA, one major company in the sector has already announced that it will also increase the remuneration of self-employed deliverers. Thus, they benefit indirectly from the minimum wage contained in the CBA. ${ }^{23}$

Finally, yet importantly, the CBA itself contains provisions that may be detrimental to the enforcement of employees' rights under the CBA. All statutory and collectively agreed entitlements of the employee arising from the employment relationship must be asserted in writing to the employer within six months of the due date, otherwise they will be forfeited. Only in the event of timely assertion of such claims shall the statutory limitation period be preserved (Article XI.5). Although such agreements are common and legal in Austria, they constitute a serious obstacle to enforcement of the law, particularly in cases of bogus self-employment.

\section{Conclusion}

In summary, the CBA for bicycle deliverers is an important step towards regulating employment relationships in this growing sector. Although the CBA contains a number of improvements as well as disadvantageous provisions, it is a significant improvement due to the minimum wage that now applies. In practice, the CBA will at first have a direct impact only on those employees already treated as employees. Over time, however, it is to be expected that there will be an increase in the identification of bogus self-employment.

\section{Comments from other jurisdictions}

Finland (Fanne Nurminen, Roschier, Attorneys Ltd): In Finland, there has recently been political discussion regarding 'the employee status' of platform economy workers such as bicycle delivery drivers. In Finland as in Austria the employment law is applicable to employees only and thus the statutory definition of an employee is crucial. Unlike in Austria, in Finland there is (yet)

22. Interview with Professor Martin Risak (University of Vienna) by Wiener Zeitung (https://www.wienerzeitung.at/nachrichten/politik/ oesterreich/2007201-Essenszusteller-bleiben-ausgeliefert.html (16.1.2020)).

23. https://orf.at/stories/3137503/ (16.1.2020). no case law regarding the employee status of bicycle delivery deliverers.

Unlike in Austria, in Finland it is optional for an employer to join an employers' association and the collective bargaining agreement coverage level in the private sector is $65 \%$. However, according to the Employment Contracts Act (55/2001, as amended) employers shall observe at least the provisions of a national collective bargaining agreement (CBA) considered representative in the sector in question (generally applicable CBA). This makes the coverage of the minimum terms of collective agreements $89 \%$ in total. However, since it is not mandatory for employers to join any association it would be unlikely that the employers would do so willingly and agree upon CBAs with the bicycle delivery drivers, who are generally not even considered employees. If there is no employer association representing the employer in the sector no CBA can be entered into (let alone a representative one) and thus no CBA can be declared generally applicable.

Even though it seems unlikely that there would be a CBA regarding bicycle delivery drivers in Finland in the near future, the Finnish Government has made an initiative towards considering the legislative measures to help the identification of artificial self-employment situations.

Germany (Ines Gutt, Luther Rechtsanmaltsgesellschaft $m b H)$ : In Germany, the employment status of bicycle deliverers mainly depends on the conditions of work, similar to the legal situation in Austria. It varies according to the respective service provider: Lieferando (Takeaway.com) riders work as employees in the first place; other riders (e.g. Deliveroo) work as selfemployed bicycle deliverers. However, the employment status of bicycle deliverers is subject to several legal disputes and union activity.

Nevertheless, CBAs in Germany can in principle also apply to self-employed persons. This applies in particular to self-employed persons who work a lot for a client, who are economically dependent and who require - like an employee - social protection. The Collective Agreement Act (Tarifvertragsgesetz) defines these persons as "persons similar to employees". In order to be considered as such a person similar to employees, more than half of the income must be earned with only one client. These persons are entitled to some special rights, e.g. paid holiday leave. And, of course, trade unions are allowed to conclude CBAs for them. ${ }^{24}$

Transferred to the present facts, this means that it would also be possible to conclude a CBA for bicycle deliverers in Germany. However, the bicycle deliverers would need to join a union in order to enable the conclusion of a CBA. According to our research, some bicycle deliverers are already supported by the union NGG (Nahrung-Genuss-Gaststätten). But the CBA would not be relevant to self-employed persons earning less than

24. https://selbststaendige.verdi.de/was-tun_1/tarifvertraege/++co+ +8457f8a6-fa91-11e2-9e35-525400438ccf 
one half of their income with only one client or nonunion members.

\section{Ireland (Orla O'Leary, Mason Hayes Curran):}

This collective bargaining agreement is very interesting from an Irish perspective, as Ireland has recently had to deal with a very similar issue.

Unlike the Austrian concept of subordination under which bicycle deliveries can operate, in Ireland anyone who is not an employee is a 'contractor'. The issue here is that a contractor, under Irish law, is self-employed, which has both employment law and revenue ramifications.

To date it has been commonplace in Ireland for delivery drivers to be hired as contractors rather than employees, potentially a form of 'bogus self-employment' as it is described in the article above. Earlier this year the Irish High Court held in a tax case called Karshan (Midlands) Limited t/a as Domino's Pizza-v-Revenue Commissions [2019 No. 31 R] that Domino's pizza delivery drivers are, in fact, employees for tax purposes resulting in Domino's being liable for PAYE and national insurance deductions. This case centred on the tax liabilities of Domino's (as opposed to pure employment law), who argued, amongst other things, that they did not have to make employer's PRSI contributions relating to their delivery drivers because they were not employees.

The Judge agreed the drivers were, in fact, employees and upheld the Tax Commissioner's interpretation of the following concepts in reaching her decision:

- Mutuality of obligations: In this case the Court found that an 'umbrella' contract existed. This meant that there was an overarching contract between Domino's and the drivers, which required the drivers to initiate an agreement with Domino's regarding their availability to work. The umbrella contract was supplemented by discrete contracts for each period of work, i.e. once Domino's rostered a driver for a shift of work there was a contract in place in respect of which both parties had mutual obligations. A material point in the assessment of mutuality of obligation was the requirement for a driver when cancelling a shift (i) to provide Domino's with advance notice; (ii) to source a substitute approved by Domino's; and (iii) to work out the remainder of the shifts agreed.

- Freedom to provide a substitute: In this case it was not possible for the drivers to pay a substitute directly. Rather, if the drivers could not do a job, a substitute was sourced from the approved roster of Domino's drivers and the substitute was paid by Domino's.

- Integration: The Court concluded that the Tax Commissioner had correctly looked at such factors as (i) to wear uniforms and place logos on their cars; (ii) to reassure customers that they were dealing with personnel of the appellant; (iii) to maintain a coherent operation under the care of the appellant; and (iv) to take telephone orders from Domino's rather than customers of Domino's.
- Terms of the contract: This was given some consideration but were reviewed "with an eye on the reality of the relationship".

It will be interesting to see how this situation continues to develop in Ireland, and if we could look towards moving closer to the new Austrian standard. 